\title{
Jungle beef: consumption, production and destruction, and the development process in the Brazilian Amazon
}

\author{
Jeffrey Hoelle ${ }^{1}$ \\ University of California, Santa Barbara, USA
}

\begin{abstract}
The environmental impacts of the global livestock industry are expected to continue increasing due to high meat consumption among affluent consumers in developed nations, and "new" consumers in emerging countries, such as Brazil. There is substantial research on the connections between international meat consumption and the destruction of Latin American environments, but less is known about the links between production/destruction and consumption in developing settings. In the western Amazon state of Acre, Brazil, increasing beef consumption is directly linked with local cattle production and environmental destruction, providing an opportunity to examine the relationships between these processes in a developing context. Interviews, participant-observation, and a standardized survey provide data on perceptions of beef and meat preferences, and how these relate to practices and patterns of consumption among a range of groups, from urban environmentalists to beef-loving cowboys. The results reveal how the hierarchical ordering of foods, with beef at the top, maps onto similar hierarchies of status and class, as well as notions of strength and nutrition. The analysis of beef consumption in a developing setting illustrates how beef is both a signifier of development and the symbolic and material fuel for a development process in which individuals, society, and the environment are transformed and improved. This study of local connections complements macro- and regional-level research on destruction and consumption linkages by offering insights on why consumers in a developing setting choose beef, and how the rubble and destruction of expanding Latin American agricultural frontiers is hidden, ignored, or written off in a discourse emphasizing the social and economic benefits of development.
\end{abstract}

Keywords: Amazonia, beef, Brazil, cattle ranching, consumption, deforestation, development, food, meat

\section{Résumé}

Les impacts environnementaux de l'industrie mondiale de l'élevage devraient continuer à augmenter en raison de la consommation élevée de viande chez les consommateurs riches dans les pays développés, et aussi les «nouveaux» consommateurs dans les pays émergents, comme le Brésil. Il existe des recherches importantes sur les liens entre la consommation internationale de viande et la destruction des milieux latino-américains, mais on connaît moins les liens entre production/destruction et consommation dans les régions moins développées. En Acre, un État brésilien dans l'Amazonie de l'Ouest, l'augmentation de la consommation de boeuf est directement liée à la production locale de bétail et à la destruction de l'environnement. Ce qui permet d'examiner les relations entre ces processus dans une région qui se développe encore. Les entrevues, l'observation des participants et une enquête standard fournissent des données sur les perceptions des préférences en matière de boeuf et de viande. Je montre comment cela se rapporte aux pratiques et aux modes de consommation parmi une gamme de groupes, allant des écologistes urbains aux cow-boys aimant le boeuf. Les résultats révèlent comment la perception hiérarchique des aliments, avec du bœuf au sommet, correspond à des hiérarchies de statut et de classe, ainsi que des notions de force et de nutrition. L'analyse de la consommation de boeuf dans un contexte de développement illustre comment le boeuf est à la fois un symbole du développement et le moteur du développement dans lequel les individus, la société et l'environnement sont transformés et améliorés. Cette étude montre les connexions locales au Brésil, et elle complète la recherche macro et régionale sur les liens de destruction et de consommation. Il offre des idées

\footnotetext{
${ }^{1}$ Dr. Jeffrey Hoelle, Assistant Professor, Department of Anthropology, University of California, Santa Barbara, CA, 93106-3210, USA. Email: hoelle "at" anth.ucsb.edu. My thanks to Casey Walsh and Javiera Barandiarán for their work organizing the "Production/destruction: Latin American environments" conference at UCSB in 2016 and this Special Section in the JPE. My thinking benefited from conversations with participants of the conference and the discussant, Gaston Gordillo. I would also like to express my appreciation to Judson Valentim, Marianne Schmink, James Nations, Tony Weiss, Mindi Schneider, David Lopez- Carr, Susanna Hecht, James Watson, Katherine Lehman, and Rick Wilk for providing crucial insights on meat consumption and production over the years. This research was supported by grants from Fulbright Foundation, the Hellman Faculty Fellowship, and the UCSB Academic Senate. This is the second article in Javiera Barandiarán and Casey Walsh (eds.) 2017. "Production/destruction in Latin America", Special Section of the Journal of Political Ecology 24: 716-800.
} 
sur la raison pour laquelle les consommateurs dans un environnement en développement choisissent le boeuf et comment les décombres et les destructions des frontières agricoles latino-américaines en expansion sont cachés, ignorés ou supprimés dans un discours mettant l'accent sur les avantages sociaux et économiques du développement.

Mots-clés: Amazonia, bœuf, Brésil, élevage, consommation, déboisement, développement, nourriture, viande

\section{Resumen}

Se espera que los impactos ambientales de la industria ganadera global, continúen su incremento dado el alto consumo de carne entre los consumidores pudientes de países desarrollados, así cómo de los de naciones emergentes, tales como Brasil. Existen abundantes investigación acerca de las conexiones entre el consumo internacional de carne y la destrucción del medio ambiente en América Latina, pero se sabe menos acerca de los vínculos entre producción/destrucción y consumo en escenarios en desarrollo. En el estado amazónico occidental de Acre, en Brasil, el creciente consumo de carne está directamente vinculado con la producción local de ganado y la destrucción ambiental, lo cual, provee una oportunidad para examinar las relaciones entre estos procesos en un contexto que está en desarrollo. Entrevistas, observación participante y una encuesta estandarizada, proveen datos sobre la percepción de preferencias de carne y res, y cómo estas se relacionan con prácticas y patrones de consumo entre grupos que van, desde ambientalistas urbanos, hasta "cowboys" amantes de la carne de res. Los resultados revelan cómo el orden jerárquico de la comida, con la carne al frente, se aplica en jerarquías similares de estatus y clase, así como en nociones de fuerza y nutrición. El análisis del consumo de la res en un contexto de desarrollo, muestra como la carne es tanto indicador de desarrollo, como impuso simbólico y material para un proceso de desarrollo en que individuos, sociedad y el medio ambiente son transformados y mejorados. Este estudio acerca de conexiones locales, complementa con investigación a nivel macro y regional sobre la destrucción y vínculos de consumo, al ofrecer diversas miradas al por qué consumidores en un medio en desarrollo escogen la carne de res y cómo el escombro y la destrucción de las expansivas fronteras agrícolas de América Latina, son escondidas, ignoradas, y escritas en un discurso que enfatiza los beneficios sociales y económicos del desarrollo.

Palabras clave: Amazonas, res, Brasil, ganadería, consumo, deforestación, desarrollo, comida, carne

\section{Resumo}

Os impactos ambientais da indústria pecuária global continuem aumentando devido ao alto consumo de carne entre os consumidores ricos nos países desenvolvidos e os "novos" consumidores nos países emergentes, como o Brasil. Há uma pesquisa substancial sobre as conexões entre o consumo internacional de carne e a destruição dos ambientes latino-americanos, mas se sabe menos sobre os vínculos entre produção / destruição e consumo em ambientes em desenvolvimento. No estado da Amazônia Ocidental do Acre, o aumento do consumo de carne bovina está diretamente relacionado à produção local de gado e à destruição ambiental, proporcionando uma oportunidade para examinar as relações entre esses processos em um contexto em desenvolvimento. Entrevistas, observação participante e uma questionário padronizada fornecem dados sobre as percepções e preferências de carne e como elas se relacionam com práticas e padrões de consumo entre uma série de grupos, desde ambientalistas urbanos até caubóis carnívoras. Os resultados revelam como a ordenação hierárquica dos alimentos, com a carne no topo, mapeia para hierarquias semelhantes de status e classe, bem como noções de força e nutrição. A análise do consumo de carne bovino num ambiente em desenvolvimento ilustra como a carne é simultaneamente o combustível simbólico e material para um processo de desenvolvimento no qual os indivíduos, a sociedade e o ambiente são transformados e melhorados. Este estudo de conexões locais complementa a pesquisa a nível macro e regional sobre as ligações de destruição e consumo, oferecendo visões sobre por que os consumidores em um ambiente em desenvolvimento escolhem carne de bovino e como os escombros e destruição nas fronteiras agrícolas latino-americanas são ocultados ou ignorados num discurso enfatizando os benefícios sociais e econômicos do desenvolvimento.

Palavras-chave: Amazônia, carne, Brasil, pecuária, consumo, desmatamento, desenvolvimento

\section{Introduction}

Picture in your mind a front end loader, heavy equipment used to move bulky and heavy materials. Do you associate this machine with the creation of infrastructure, industry, homes or agricultural fields? Or, do you see a tool of destruction, plowing through forests, irreplaceable archaeological ruins, or poor and working class neighborhoods? Both of these processes are linked in the "creative destruction" required for capitalist expansion (Schumpeter 1942), but depending on one's perspective, these same transformations may 
be understood negatively, as destruction, or positively, as production. One's interpretation may also vary depending on when and where the transformations are occurring. The front end loader that I am describing is chugging through the Amazon rainforest. A man in a baseball cap sits in the driver's seat, throttling the machine forward, through the mud and into the blurry forest ahead. Hoisted high in the loader's bucket is....what? The actual contents of the bucket would be difficult for anyone to predict, but those oriented to seeing Amazonian transformations as destruction might fill it with imagined rubble, debris, or remnants of the rainforest. This particular loader brings forth an enormous hamburger (Figure 1). Specifically, it carries one of the biggest hamburgers on the menu at the McNaldão (Big McNaldo) hamburger stand: the "McNaldão Mega Power", loaded with 500 grams of beef, as well as sausage, bacon, two hot dogs, fried egg, steak, chicken, cheese, ham, tomato, lettuce, beets, and corn.

This image adorns the front of the McNaldão's hamburger stand in Rio Branco, the capital of the western Amazon state of Acre, Brazil. The presence of McNaldão is particularly difficult to imagine in Acre, the "greenest" state in the Brazilian Amazon and one with a history of resistance to the expansion of cattle. In the 1970s, the military government opened the Amazon to colonization, leading to widespread deforestation and social conflict (Schmink and Wood 1992). Following the opening of the BR-364 highway to the remote western state of Acre, migrant ranchers and settlers arrived to claim land and convert standing forest to cattle raising and agriculture. These migrant groups came into conflict with rubber tappers who had been in the region since the mid-1800s. The rubber tappers, who relied on the forest for rubber, Brazil nuts, and other products, mobilized to protect their forest livelihoods (Bakx 1988). The rubber tapper social movement attracted international attention in their struggle against cattle raising and the military development model based on forest transformation to agriculture (Keck 1995). In the 1990s, the rubber tapper model of forest extractivism spread throughout the Amazon as the basis for the extractive reserve system, a use-based conservation model (Gomes 2009). The state of Acre built on the rubber tapper legacy, particularly during the administrations of the "forest" government (1988-2010), which implemented a series of policies to support sustainable rural livelihoods (Schmink et al. 2014). Acre is thus known across the world as a site of resistance to cattle-driven deforestation and for policy initiatives balancing economic development and forest conservation (Kainer et al. 2003).

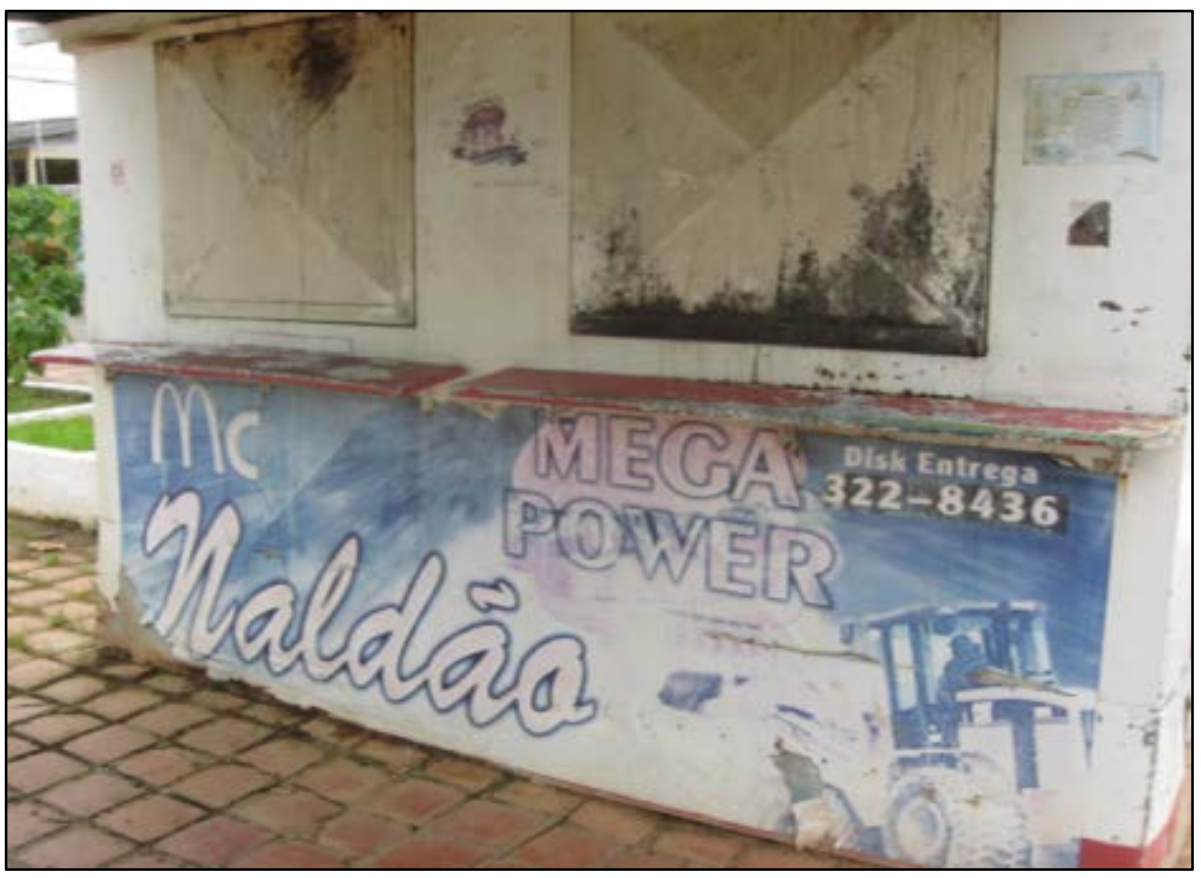

Figure 1: McNaldão hamburger stand. Rio Branco, Acre, Brazil. Photo taken by the author. 


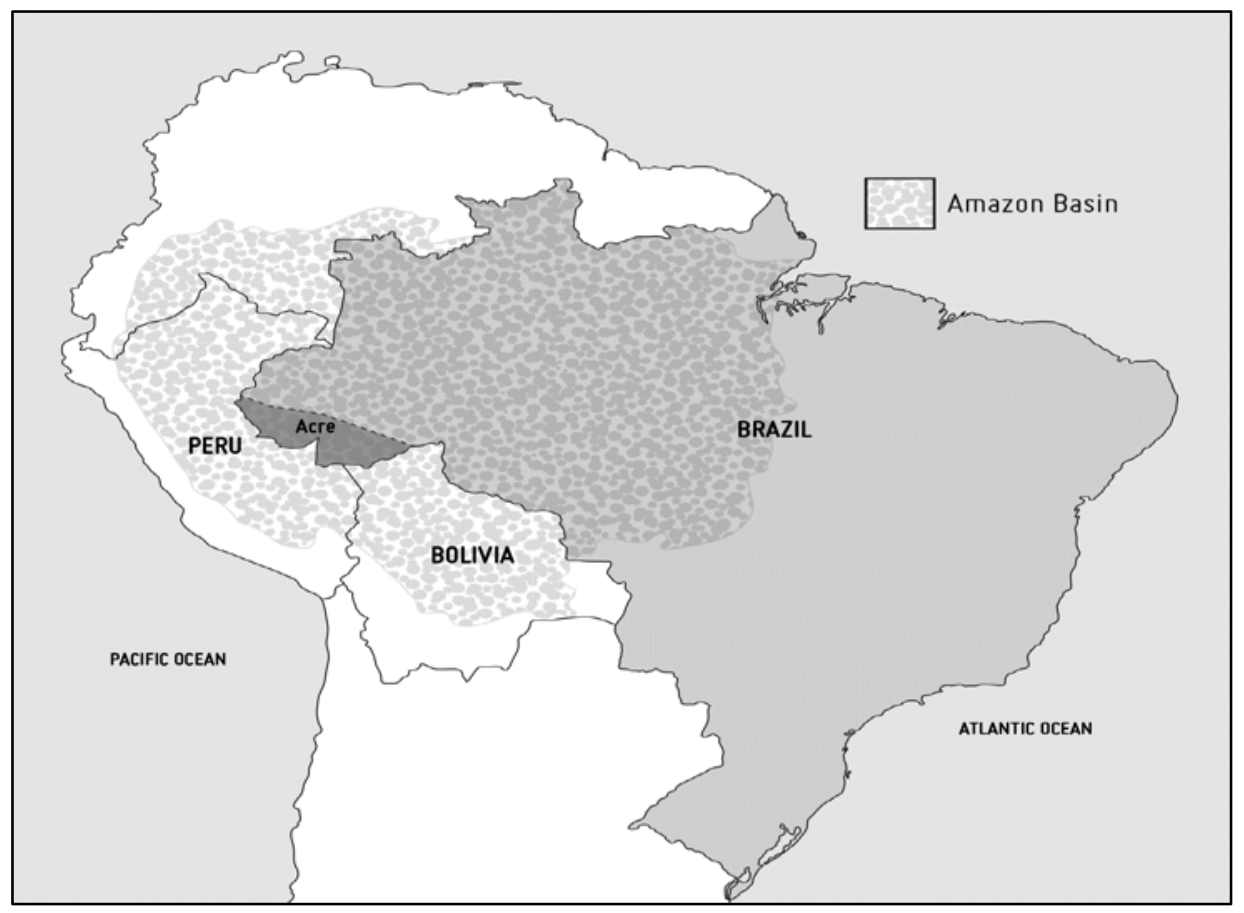

Figure 2: Map of Acre, Brazil.

McNaldão's hamburger stand and its meaty imagery may seem incompatible with Acrean history and politics, but both are reflective of the growth of the cattle industry and increasing beef consumption occurring throughout the state. In fact, developments in Acre are indicative of trends throughout the Brazilian Amazon, where the expansion of cattle raising - the leading driver of deforestation-has contributed to Brazil's rise to the top of global beef exports in the last decade (FAOSTAT). However, research on tropical deforestation and developed-nation consumption (e.g. Myers 1981) only tells part of the story. In recent years, consumption has increased among "new" consumers in developing countries (Myers and Kent 2013), and in Brazil, internal beef consumption was actually several times greater than beef exports in 2013 (FAOSTAT). The beef produced in Amazonia is shipped to "developed" regions of southern Brazil, but much of it stays in Amazonia, where beef consumption rates are among the highest in the nation (IBGE POF 2010). An analysis of beef consumption in Acre, where rising consumption and rainforest destruction are directly linked, complements macro-level research on international connections through a focus on local connections. Given that Acre is a developing context where standards of living are improving, this analysis also deepens our understanding of why new consumers choose to consume more beef or meat when they are able to afford it.

In order to understand why Acreans value beef, it is necessary to revisit the symbols on McNaldão's sign: heavy machinery in the forest, the hamburger, and the golden arches. Each of these elements is studied in environmentalist research and propaganda associated with the 'hamburger connection', which seeks to understand rainforest conversion to pasture and meat consumption as negative transformations that produce harmful environmental effects (Greenpeace 2015; Myers 1981). But McNaldão's image does not feature 'rubble' or byproducts of forest destruction in the loader's bucket; instead there is a product at the downstream end of the commodity chain - a gigantic hamburger. McNaldão's sign, along with increases in cattle production and beef consumption, suggests that local consumers may see the environmental and social transformation of the rainforest as positive. While macro-level analyses and much Amazonian political ecology research casts consumption and destruction in a negative light, shifting the focus to local cultural beliefs and practices surrounding beef shows how consumption and production are positively charged. 
Agricultural frontiers are expanding across South America, providing increases in production through the modernization of traditional practices and the transformation of previous forests and environments to new agricultural lands (Barona et al. 2010; Pacheco 2012; Zycherman 2016). In the soy frontier of the Argentine Gran Chaco, Gaston Gordillo describes rubble as the formless remnants of progress; piles of bricks and dilapidated buildings speak of previous social formations destroyed or left behind by progress (2014). Rubble reveals the negative dimensions of the creative destruction that is the "essential fact" of capitalism (Schumpeter 1942). The elite dispositions of academics, the state, and other outsiders may fetishize rubble as "ruins" to be preserved, or see it as evidence of the destruction generated by relentless capitalist expansion. For locals, however, rubble may be ignored, destroyed or moved aside to make way for the next wave of agricultural development and jobs (Gordillo 2014). Similarly, many Acreans welcome the transformation of tangled forests to "clean" pastures, geometric agricultural fields, modern cities, and paved roads (Hoelle 2015). An anthropological focus on locally cherished consumption, rather than highly scrutinized production/ destruction, can help to better understand how the rubble of the cattle-beef industry is largely invisible, ignored, or written off as the inevitable price of progress by the actors shaping agricultural frontiers.

In this article, I first outline research on meat consumption, production, and environmental destruction, scaling down from global dynamics to focus on Brazil and the Amazon region, where the agricultural sector is booming, standards of living are rising, and meat consumption is increasing. Drawing on perspectives from Amazonian political ecology and anthropological and geographical studies of food, I build a framework for studying beef consumption and perceptions in Acre across a range of very different groups with distinctive views on cattle, development, and environment, including urban environmentalists, cowboys, and forest-dwelling rubber tappers. Drawing on ethnographic observation, interviews, and a standardized survey on meat and beef perceptions and practices, I examine the local considerations that structure consumption according to factors such as socioeconomic status, rural/ urban residence, type of labor or profession, and ideology. Finally, I discuss local cultural beliefs linking meat and beef with nutrition, status, and strength and explain how these map onto influential discourses of linear development in which the individual, society, and the environment are improved.

\section{Shifting dynamics of livestock production, meat consumption, and environmental impacts across scales}

The international connections between tropical forest destruction and meat consumption began to reach public and academic attention in the early 1980s. In subsequent decades the dynamics of production and consumption have shifted while the environmental impacts have become more evident. The term "hamburger connection" is most commonly associated with Norman Myers' influential article (1981) in which he drew attention to destruction of Mexican and Central American rainforests for cheap beef used in North American hamburgers. The links between deforestation and consumption were further elaborated and revised in other studies with alarming titles, including The cattle are eating the forest (DeWalt 1983), Hoofprints on the forest (Shane 1986), and Rainforests and the hamburger society (Nations and Komer 1983). In this dynamic of ecologically unequal exchange, impoverished Latin Americans degraded their lands and but did not benefit from an improved diet - "eating less meat than the average American cat" (Nations and Nigh 1978). Subsequent research demonstrated that these core-periphery connections vary across time and are driven by international as well as national and regional-level drivers (Austin 2010; Browder 1998; Edelman 1995; Hecht 1993). In recent decades, the emergence of new consumers and complex production chains has blurred the binaries of core consumers and peripheral production and destruction (Weis 2013). Livestock continue to graze on pastures created from deforestation, but the expansion of the livestock industry providing an increasing supply of meat is also linked to the development of Concentrated Animal Feeding Operations (CAFOs) reliant on grains and oil seeds (Oliveira and Hecht 2016).

The sheer increase in global meat production is remarkable. In 1961, approximately 3 billion people ate $23 \mathrm{~kg}$ of meat a year, while in 2011, the figures were 7 billion people eating $43 \mathrm{~kg} / \mathrm{year}$, with milk, eggs, and other animal products also increasing substantially (Weis 2013). By 2050, the FAO estimates that this figure will rise to $52 \mathrm{kgs} / \mathrm{year}$ for a global population of 9.3 million (ibid.) Increasing meat and animal product consumption is not related solely to population growth. Affluent and "new" consumers in 
industrializing and developing countries consume an inordinate amount of meat compared to the rest of the world. For example, in 2010 consumers in a handful of countries - the United States, Australia, New Zealand, Argentina, Canada, and western Europe - accounted for one-third of all meat consumption, whereas in South and Southeast Asia, home to about half of the world's population, only $16 \%$ of all meat was consumed (Weis 2013: 84). While consumers in developed nations remain the highest consumers of meat and animal products, rates of consumption have slowed and are expected to level off or in some cases actually decline (Chemnitz and Becheva 2014). The focus of much research and policy has shifted to "new" consumers in dozens of emergent countries, including China and Brazil, with purchasing power that enables the acquisition of items perceived as prerequisites of an affluent lifestyle, such as household appliances, cars, and meat-based diets (McAlpine et al. 2009; Myers and Kent 2013).

The livestock industry tends to impact poor and rural populations more than the urban consumers enjoying increased meat in their diets. This inequality is distributed internationally and regionally according to an "uneven geography of meat", in which wealthier consumers in developed and developing countries have access to a wide selection of meat and dairy products while the ecological costs of production are diffused locally and globally (Weis 2013). Within countries, rural areas may serve as a "sink" for the environmental costs of increased production (Schneider 2015). Globally, it is estimated that the livestock industry contributes $18 \%$ of global GHG emissions (Steinfeld et al. 2006), with some estimates going as high as 51\% (Goodland and Anhang 2009). Beef production creates the greatest environmental burden and requires much more land and irrigation water, other livestock categories (Eshel et al. 2014) Overall, increases in livestock production and meat consumption have resulted in what Tony Weis terms the "ecological hoofprint" in which livestock and meat are implicated in exacerbating global inequality and a host of environmental, social, and health problems (Weis 2013).

Brazil is a developing country that illustrates the complex and changing nature of global production, environmental destruction, and consumption linkages. In 2013, Brazil was among the top producers and exporters of key commodities, including beef, chicken, and soy. Brazil was the second largest producer of soy and the number one exporter (FAOSTAT). The majority of Brazilian soy is sent to China for pig feed (Oliveira and Schneider 2016), and it is also used for feed in the Brazilian poultry industry, the largest in the world (FAOSTAT). ${ }^{2}$ Soy production is increasing dramatically in the more centralized regions of the cerrado and southern Amazonia, pushing settlement and cattle raising into the more remote areas of the Amazon, where land is cheaper (Arima et al. 2011; Barona et al. 2010).

From 2000 to 2014, the numbers of cattle in Brazil rose from 170 to 213 million, only surpassed by India, where religious beliefs limit slaughtering for meat (FAOSTAT). Cattle production has steadily increased in the Amazon region and now accounts for an estimated $40 \%$ of the national herd. The conversion of forest to cattle pasture is the primary driver of Amazonian deforestation (INPE 2016), and the majority of the nearly seventy-five million hectares of deforested lands in the Brazilian Amazon are cattle pastures (IBGE 2016). Between 2000 and 2013, Brazil also led the world in bovine meat exports, averaging 1.3 million kilograms per year. In 2013 alone, Brazil produced an estimated 9.67 million tons of beef, shipping 1.6 million tons abroad along with 688,641 live cattle. While these export numbers are impressive, they pale in comparison to the amount of beef consumed in Brazil, which is more than five times that of beef exports (FAOSTAT).

The increasing production of Amazonian agriculture and cattle raising, coupled with its distance from markets and elevated transport costs also means that there is a steady supply of cheap beef for Amazonian consumers (Faminow 1997). With standards of living improving and the majority of Amazonian residents now living in cities (Vadjunec, Schmink and Greiner 2011), meat and beef consumption have expanded throughout the region since 2000, with many Amazon states at the top of per capita consumption rankings in Brazil (IBGE POF 2010). Despite the conflict surrounding cattle and the emphasis on sustainable policies in Acre, cattle raising has steadily increased in the state, from 72,000 head of cattle in 1970 (Censo Agropecuário 2006) to an estimated 2.8 million head in 2014 (IBGE 2016). Standards of living have also

\footnotetext{
${ }^{2}$ The FAO figures come from estimates for 2013 and were accessed online through FAOstat.org. The numbers for export, consumption, and production come from different FAO domains: export- "trade", consumption- "food balance/ food supply", and production- "production."
} 
improved for many Acreans, especially in cities (Schmink and Cordeiro 2008). Beef was once a luxury in Acre, but it is now cheap and widely available. According to one estimate, Acrean beef consumption is the highest in all of Brazil, with residents eating an average of 42.25 kilograms of beef a year (Valentim 2012).

\section{A conceptual framework for studying production and consumption in Amazonia and developing settings}

Much of the previous research focuses on increasing meat consumption and links it with environmental impacts or socioeconomic drivers. These linkages are analyzed at regional, national, or international scales using secondary data and economic indicators to understand connections and patterns between consumption, socioeconomic status, animal/oilseed production, and environmental destruction. Most of these macro-level studies devote less attention to internal connections in developing settings and the local social, ecological, economic dynamics in which consumption, production, and destruction are directly linked (Hecht 1993). Here I draw on perspectives from political ecology and social scientific studies of food and consumption to build an analytical framework for a place-based ethnographic study of consumptionproduction/ destruction dynamics in a developing setting.

Foundational political ecology texts analyzed the opening of the Brazilian Amazon to colonization and investment beginning in the 1970s and the resulting social conflict and environmental destruction (Bunker 1985; Hecht and Cockburn 1989; Schmink and Wood 1992). These and other accounts focused primarily on struggles over ownership and class conflict in rural and forested frontier areas (Foweraker 1981) and the development policies, incentives, and subsidies driving conflict and deforestation (Hecht 1993). Environmental change and policy research on beef consumption documented the changing patterns of rainforest destruction as it related to growing consumption in the Amazon region, in Brazil, and internationally (Faminow 1997; Kaimowitz et al. 2004; Uhl and Parker 1986). Current research builds on this legacy, examining the connections between deforestation, cattle production, processing, and distribution with the aim of curbing cattle-driven deforestation through interventions at different points, such as Amazonia production (Gibbs et al. 2015) or consumption in Brazil and internationally (Greenpeace 2015).

Although the previous research on production/ destruction and consumption varies in methods, scale, and discipline, much of it shares an overarching focus on negative social and environmental outcomes, resulting from either deforestation or beef consumption. These negative impacts are connected with relevant structural features, such as policies, market forces, and inequality. Less attention is devoted to the symbolic and discursive features of the regional political economy, or to local perspectives, which may see "destruction" positively through an ideology of development emphasizing progress and self-improvement (Campbell 2015; Hoelle 2015). Overall, Amazonian political ecology and environmental change research tends to focus on destruction and other negative transformations occurring in rural areas or forest frontiers, with less attention on the local connections between forest destruction and consumption or the social and cultural context that helps to more fully explain factors fueling consumption.

Anthropological studies linking consumption and production contextualize these economic processes in relation to political economy and local cultural beliefs and practices, but often with a focus on first-world consumption and third-world production (e.g. Besky 2013; Lyons 2010). In these global north-south connections, the narratives and discourses surrounding specialized products map onto the politicized consumption practices of developed-nation consumers. The imagination of Amazonian products builds on consumer visions of a land of nature and indigenous people, and consumers pay more to support a vision of social and environmental justice. For example, by purchasing Rainforest crunch ice-cream, buyers help preserve the Amazon rainforest - "the lungs of the world" and "a place of dreams" (Bryant and Goodman 2004). Less studied are the links between consumption and production in developing contexts, such the focus here on Amazonian consumption of Amazonian products. As McNaldão's sign illustrates, Acrean consumers may be motivated by an entirely different set of politics and values that would be difficult to understand from the perspectives of Northern consumers.

Anthropological studies of food and eating are particularly well-suited to situate consumption in relation to local cultural beliefs, social context, and political economy. Cross-cultural comparisons reveal that a particular food may be embraced in one setting or time, only to be taboo or prohibited in others (Harris 1998; Simoons 1984). Food may be a commodity, a good, or a source of sustenance and nutrition, but these 
categories are not fixed and may be expressed differently at different times, places, and contexts (Mintz 1985; Wilk 2002). The physical properties and benefits of foods are constructed culturally as nutritious or dangerous (Douglas 2003), indicative of group identity based on nationality, ethnicity or race, and class (Mintz and Dubois 2002; Fajans 2013), and reflective of status and social hierarchies (Bourdieu 1984; Walsh 2004).

In summary, political ecology and macro-level analysis often study these two economic processes by framing them negatively as destructive or producing harmful environmental impacts, making it difficult to understand the interlinked political economic and cultural system in which consumption is seen positively and linked with production (Heyman 2005). While anthropological studies help to understand consumption within local value systems, it is less common to connect production and consumption in the local developing context. By combining ethnographic findings on the meanings of beef and contextualizing consumption in relation to a conceptual system of development, a local focus can complement macro-level perspectives and political ecology research that seeks to understand the drivers and impacts of these destructive processes (Zycherman 2016).

\section{Methods}

This research was conducted over the course of 22 months of fieldwork from 2007-2010 and in 2013, 2015, and 2016 in rural and urban locales in the southern of region of Acre. Data were collected using semistructured interviews, participant observation, and a standardized survey. Throughout the course of this research I conducted participant observation at numerous churrascos and other events in which meat and beef were consumed, including meals with families, at different types of restaurants, and during lunch breaks with urban and rural workers. To understand the categories and meanings of meat and beef, I interviewed key informants, such as restaurant owners, consumers, vegetarians, butchers, and grill masters at churrascarias.

Specific perceptions about meals and meat were very common and were revealed in these and other settings during the first twelve months of fieldwork. Some of the most common statements that I heard were that beef provided more resistência (endurance) and that a meal with no meat was not a meal. I created a standardized survey comprised of these and other statements and administered it to twenty members of six different groups. The sample included a broad cross section of Acrean society, with the aim of better understanding the perspectives of those involved with the cattle industry (agricultural colonists, large scale ranchers, and cowboys), as well as those with more of an orientation to forest preservation, including the forest-dwelling rubber tappers, and urban policy makers in the forest government and decision makers at socio-environmental NGOs. These groups differ in terms of their class, education level, and the nature of the work - features that will be discussed in more detail in the comparison. I also administered an urban survey to twenty respondents residing in Rio Branco. These were chosen based on pre-defined quota with equal numbers of upper-class professionals $(\mathrm{N}=10)$ and working class respondents $(\mathrm{N}=10){ }^{3}$

\section{Perceptions of beef and consumption in Acre}

\section{The meal and the meat}

Brazilians distinguish between types of food and specific ways of combining these elements to create a meal that is considered physically and psychologically satisfying. While one may satisfy basic requirements by eating any number of different foods, eating a meal satisfies cultural expectations of both sustenance and the performance of Brazilian identity (Fajans 2013). Eating a meal does not necessarily mean eating at a certain time or place, but is related to fulfilling the social expectations for each type of meal by eating from a range of acceptable foods (Douglas 1972). For example, breakfast could be considered complete with sweet coffee and bread with butter, while the menu for a respectable lunch requires a combination of rice, beans, and meat. The typical meal that one might encounter in one of the popular prato feito (composed plate) restaurants in Acre would include these elements and a small amount of spaghetti, salada (usually a lettuce

\footnotetext{
${ }^{3}$ For more information on the survey, the sample, and other methodological details, see Hoelle (2015: 148-161; 171-
} 176). 
leaf and a slice of tomato), and juice or soda. Some combination of these foods would also be found in lunches eaten at home and in the marmita or marmitex (to-go meals sealed tin foil plates from restaurants or lunch pails brought from home) at job sites and offices around the city.

Along with feijoada, beef is considered to be a national food and Brazilians take great pride in their churrascos, or barbecues (Fajans 2013). Churrascos are very common in Brazil, bringing friends and family together on the weekends, and to celebrate life events, such as birthdays and graduations, as well as holidays and important soccer matches. At the ubiquitous churrascarias (barbecue restaurants) of Acre, one may eat an unlimited amount for a set price (rodizio) or pay by the weight of the food (per kilo). People tend to go to these establishments for the express purpose of eating grilled beef, as well as sausage, pork, and chicken. In the per kilo restaurants, customers go through the line of foods first, and then arrive at the grill with their plates already loaded with complements. Even in this meat-oriented setting, where price is determined by weight - not the price of the item, it is rare to see a plate that does not have substantial helpings of rice and beans. This is but one example of the ways in which shared cultural beliefs structure consumption patterns in a way that defies purely economic calculations.

While notions of a good meal include meat and complements, having some source of meat or animal protein is considered essential to many consumers. This was especially true for lunch, the largest and most important meal of the day. Many Acreans often said that lunch with no meat "was not a real lunch." Respondents said that such a vegetarian meal would be "eaten with eyes closed", "not filling", or "make a person weak." When I asked respondents in eight groups if they agreed or disagreed that a lunch with no meat is not a lunch, 58\% agreed (see Table 1). This overall percentage reflects widespread agreement among five groups (ranchers, rubber tappers, colonists, policymakers, and urban workers) with average agreement of $67 \%$. NGO (20\%) and urban professional (40\%) respondents agreed notably less with this statement.

Another common statement that I heard was that "a lunch with no meat leaves a person weak." Ninety percent of rubber tappers agreed with this statement, as did an average of $70 \%$ of colonists, ranchers, urban working class, and cowboys. On the other end of the spectrum, only $40 \%$ of urban professionals, $35 \%$ of policymakers and $15 \%$ of NGO respondents agreed. For these two questions, which both focus on meat, we see similarities among rural groups and the urban working class, who all make a living through physical labor (and ranchers who do not perform physical labor but who are invested in the cattle industry). These groups agree more with positive perceptions of meat than groups in the urban-professional category. The ruralworking class groups, especially, saw meat as an essential source of energy and strength required to perform manual labor. Many urban professionals, on the other hand, stated that eating too much meat for lunch could produce moleza (lethargy).

NGO, policymakers and urban professional groups are similar in that they had higher levels of education (college or graduate degree) and higher income than rural and working class groups. The results show that these urban professionals were less positive about meat than rural groups, and interviews revealed critical views of meat, including acknowledgement of negative environmental and health impacts. Of all groups, NGO employees disagreed the most with positive statements about meat. This is a reflection of their ideological and political perspectives. All of the NGO respondents worked in jobs dedicated to smallholder social justice and sustainable livelihoods and held negative view of the cattle raising industry. Although ranchers are similar to NGO and other urban professionals in their location, socioeconomic status, and level of education, they have a different political view of rural development and are directly invested in the cattle industry. Rancher responses are thus more closely aligned with rural and working class groups. With the exception of the ideological considerations of NGO and rancher groups, we see that urban location, professional class, and higher education and income are related to less positive perceptions of meat, while rural location, working class, and lower education and income are more positive. 


\begin{tabular}{|c|c|c|c|c|c|c|c|c|c|}
\hline & \multicolumn{3}{|c|}{ Urban-professional groups } & \multicolumn{5}{|c|}{ Rural-working class groups and ranchers } & \multirow{2}{*}{$\begin{array}{l}\text { Overall } \\
\text { agree. } \\
\text { question }\end{array}$} \\
\hline & NGO & $\begin{array}{l}\text { Urban } \\
\text { professionals }\end{array}$ & $\begin{array}{l}\text { Policy- } \\
\text { maker }\end{array}$ & $\begin{array}{l}\text { Rubber } \\
\text { tapper }\end{array}$ & Rancher & Colonist & $\begin{array}{l}\text { Urban } \\
\text { worker }\end{array}$ & Cowboy & \\
\hline $\begin{array}{l}\text { A lunch with } \\
\text { no meat is not } \\
\text { a lunch }\end{array}$ & $20 \%$ & $40 \%$ & $60 \%$ & $55 \%$ & $70 \%$ & $75 \%$ & $70 \%$ & $70 \%$ & $58 \%$ \\
\hline $\begin{array}{c}\text { A lunch with } \\
\text { no meat leaves } \\
\text { a person weak }\end{array}$ & $15 \%$ & $40 \%$ & $35 \%$ & $90 \%$ & $65 \%$ & $70 \%$ & $70 \%$ & $75 \%$ & $58 \%$ \\
\hline $\begin{array}{l}\text { Beef gives } \\
\text { more strength } \\
\text { to work } \\
\text { than other } \\
\text { foods }\end{array}$ & $20 \%$ & $60 \%$ & $35 \%$ & $45 \%$ & $65 \%$ & $70 \%$ & $80 \%$ & $100 \%$ & $59 \%$ \\
\hline $\begin{array}{l}\text { People who } \\
\text { don't eat beef } \\
\text { lack the will to } \\
\text { work }\end{array}$ & $0 \%$ & $0 \%$ & $15 \%$ & $25 \%$ & $40 \%$ & $55 \%$ & $60 \%$ & $55 \%$ & $31 \%$ \\
\hline $\begin{array}{c}\text { Overall } \\
\text { agreement by } \\
\text { group }\end{array}$ & $14 \%$ & $35 \%$ & $36 \%$ & $54 \%$ & $60 \%$ & $68 \%$ & $70 \%$ & $75 \%$ & \\
\hline
\end{tabular}

Table 1: Agreement with positive meat and beef perceptions, by social group. The percentages are the amount of respondents (out of 20) for all groups, except the urban office professional and urban worker groups, which had 10 respondents each. The percentages are shaded on a gradient from green (low agreement) to red (high agreement) to illustrate differences between in agreement between groups and questions. The bottom row is the average agreement by group for all questions, and the far right column is the average agreement for each question across groups.

\section{Beef, strength, and work}

Meat is considered an integral part of meals, but not all meats are perceived as providing equal benefits. Many interviewees noted that beef provided more resistência, or that it stuck with you through the afternoon, giving the strength to work and a full, satisfied feeling. The nutritional properties of meats were often related to personal experience and to what respondents had been taught growing up. They often cited scientific facts learned from government education and television programs to support their ordering of meats.

Types of meat were ordered on a ranked scale according to perceived taste and physical or nutritional benefits. For most Acreans, beef was at the top of the meat pyramid, followed by the more leve (light) or fraco (weak) meats, such as chicken and fish. Some said that pork and wild game (red meat) was close to or equal to beef in terms of strength, but these meats were less appreciated for reasons such as unique taste, health concerns, and limited supply. A boiled egg was considered the minimal form of acceptable protein.

Numerous Acreans said eating beef produced maximum physical benefits compared to other types of meat, a point illustrated through comparisons. For example, it was said that beef provided Brazilians with their larger stature and strength in comparison with their neighbors across the border, who preferred chicken 
and eggs (Peruvians) or pork (Bolivians). These comparisons were also made within Brazilian society. On quite a few occasions, people said that those who did not eat meat (vegetarians) or for whom access to meat was infrequent (indigenous and poor) suffered from poor health and a lack of will to work (falta de coragem). Beef perceptions reveal how local conceptualizations of development are based on personal socioeconomic improvement, but eating beef is also considered essential to providing the energy necessary for environmental transformations that are indicative of the development process (Hoelle 2012).

Pro-beef statements were common in conversations and interviews, giving the impression that they were widely shared. However, survey results show that these perceptions may be more indicative of specific groups. In terms of the most powerful fuel for labor, beef was at the top of meat hierarchies, but when I asked if "beef gives more strength to work than other foods" on the survey, responses varied significantly. All cowboys agreed with this statement, and the majority of colonists, urban working class, and ranchers also agreed. Few NGO staff (20\%) and policymakers (35\%) agreed, but $60 \%$ of urban professional answered yes. Overall, we see lower levels of agreement with this beef-specific question compared to the more general question about a meatless lunch, but with roughly similar divisions among rural and urban groups.

When asked if "people who don't eat beef lack the will to work," only $31 \%$ of all respondents agreed. Levels of agreement were lower than for all previous items for each group, although similar distinctions between urban professional and rural/working class and rancher groups are evident. While people said this exact phrase in normal speech, the negative framing of the question may have influenced the responses on the formal survey. Unlike previous questions, this one asks respondents to evaluate people (instead of food) and link them with a negative attribute, which would be considered inappropriate or impolite. Despite these and other limitations of standardized surveys, they provide results that complement a purely qualitative approach. In this case, it is useful to know how pro-meat and beef perceptions are distributed across groups with very different characteristics. How are these perceptions related to patterns of beef consumption?

\section{Meat and beef consumption by group}

The survey results provide a general sense of how meat and beef perceptions are structured by factors such as rural/ urban location, manual labor or professional work, ideology, and livelihood. Based on these patterns, it would be expected that groups with less positive perceptions of beef would eat less, and those who were more positive would eat more. We might also expect that urban professionals dedicated to environmental concerns (NGO and policymakers) would eat less beef than rural groups who make a living from cattle or agriculture. Yet, when I asked respondents how many days a week they ate beef, the results were surprising, overall and especially among groups with less positive perceptions of meat.

Cowboys ate beef the most often 6.6 day a week, a high figure that is the result of their employment on ranches where beef is provided on a daily basis by the rancher/ owner as part of their labor agreement. Ranchers and colonists reported eating beef an average of 5.9 and 5.6 days a week, respectively. Urban professional (5.1 days/week) and working class (4.4 days/ week) also ate beef often. Many of these respondents reported eating beef every day, abstaining only during Semana Santa (Holy Week). Urban policymakers and NGO workers had lower rates of beef consumption, but were still high at 3.9 and 3.8 days per week, respectively.

On the other extreme, rubber tappers had very low measures of beef consumption, with many reporting that they only ate beef on their occasional visits to the cities. This low rate is attributable in some respects to the fact that they are the poorest of all groups, but also because they are far from the city, and rely on roads that are not passable for parts of the year. Unlike other rural groups, the tappers did not have electricity for beef storage, which limited the amount of beef they brought home with them after visiting the city, where cheap beef is available. Although they eat limited beef, rubber tappers nonetheless consider meat to be an important element of their diet, and reported that most of the meat they ate came from hunted game.

The consumption figures illustrate widespread consumption of beef, based on availability, price, and shared preferences. Ideological and perceptual differences reported in the previous sections were reflected in the lower consumption rates of policymakers and NGOs, but these were not as low as expected. Within groups there were cases in which people rejected beef, but most of these individuals reported that they were forced into this position for health reasons. 


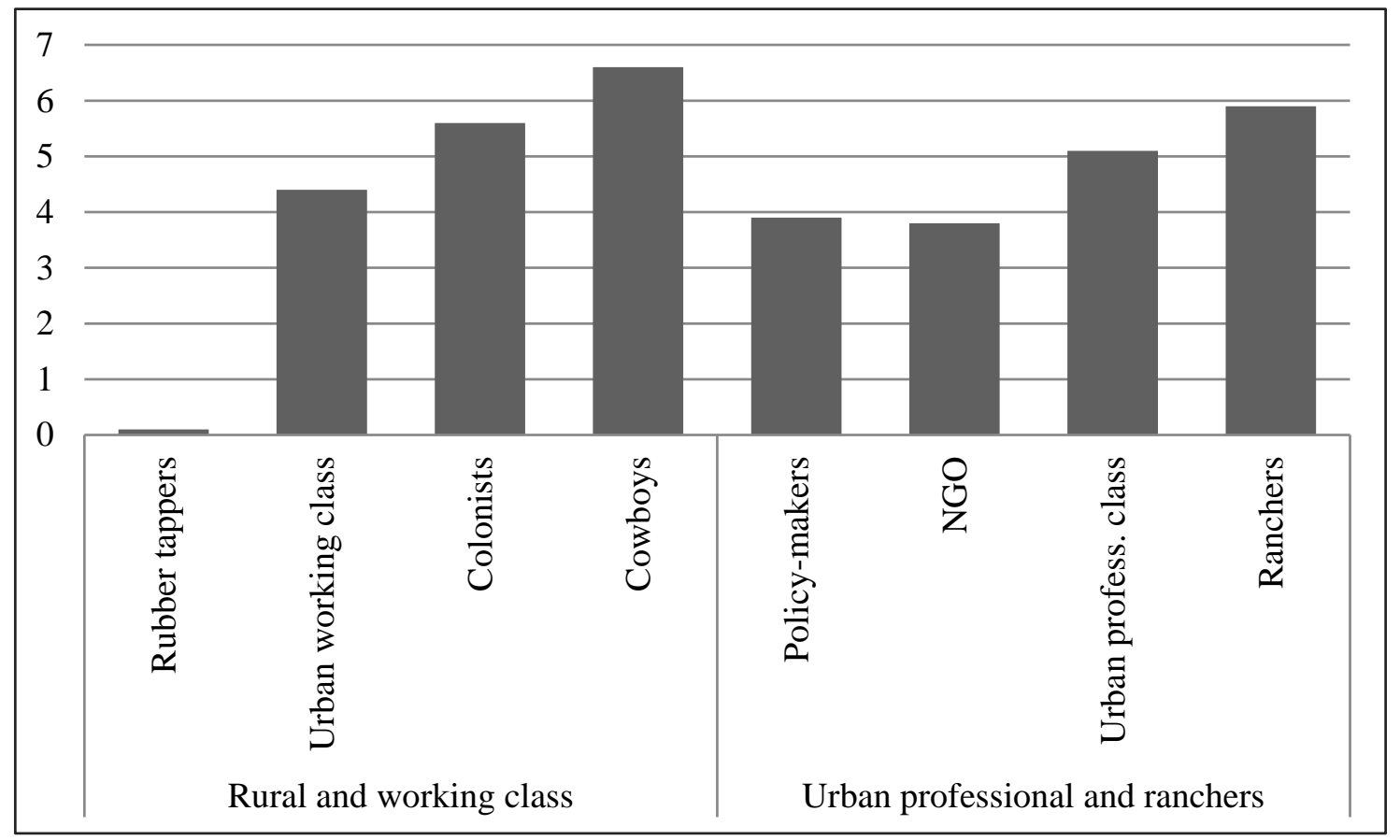

Figure 3: Beef consumption (average number of days beef consumed per week, by group).

The rubber tappers' low rates of beef consumption were related to their uniquely remote location. They could afford cheap beef, but it was only accessible in the cities and they did not have the ability to store beef because the rural electrification did not extend to their distant community. The minimal beef consumption of the tappers is related more to access and storage, rather than a lack of purchasing power or the rejection of positive meat and beef perceptions. The fact that all other groups ate beef almost four days a week also demonstrates the limited influence of other variables, such as class, urban/rural location, education, and ideology. Overall, the high rates of beef consumption reflect the centrality of beef in Brazilian society and the particularly strong enthusiasm for beef during a period of time when beef was abundant and cheap, following years of scarcity.

\section{Meat, beef, and status}

The hierarchical ordering of meats maps onto notions of status and class, which are also ranked from low to high. Even if people have unique preferences or guidelines, they recognize these parallel hierarchies of status and meat. These categories are reinforced in social situations, where it is important to know what foods are acceptable for a guest to feel that their status has been acknowledged. The parallel ordering of meats and status is illustrated in Ascenso Ferreira's classic poem Fazendeiro (1951).

Hey Maria! Maria! Compadre Cazuza is coming to have lunch, tomorrow at our house... What did you make for him?

I killed a hen, I killed a duck, I killed a turkey, I killed a pig...

Oh Lordy, woman! Are you thinking that my friend Cazuza is a pinto ("chick," or insignificant person)?! Go kill a bull!! 
The status-meat parallels noted in the poem were illustrated on numerous occasions during private lunches and dinners, and at public events in which there were people of different statuses and limited amounts of preferred cuts of meat. Higher ranking employees and leaders, as well as special guests and elders were offered their choice of meat or given the best cut without discussion.

Beef is at the top of the meat hierarchy in notions of strength, taste and endurance, but it is also seen as indicative of higher social status. Within the beef category, status and social standing are further subdivided according to specific cuts of beef. The top cuts, picanha (top sirloin, rump cover/cap) and filé (filet mignon) were seen as delicious and emblematic of the vida boa (good life). Specialists with intricate knowledge of beef, such as butchers, as well as everyday consumers recognize the hierarchy of beef cuts, from high to low quality. This quality is related to price and the relative amount of any given cut on a carcass as well tenderness, taste, and appearance. In the standardized survey, I asked respondents to indicate their favorite type or cut of beef. This cut was then coded according to its location on a scale from 1 (lowest quality- e.g. hoof, organs) to 4 (e.g. highest quality - picanha, file).

When I asked respondents to tell me their favorite cut of beef (which they may or may not actually consume on a regular basis), many indicated one of the high quality cuts. One respondent chose picanha and then added, with feigned sophistication, "porque sou chique" (because I am "chic" or fancy). At the lower levels of the beef hierarchy were organs and hooves, the cheapest and least desirable parts of the cow. Some lower quality cuts of meat, such as ribs, hoof, and tail are valued across class lines for special dishes and stews, and may be consumed by Brazilians of all classes on certain occasions. Under normal circumstances, though, members of all groups were able to differentiate between high and low quality beef cuts and were particularly aware of the top cuts. Broadly speaking, these higher and lower quality categories were eaten by consumers of higher and lower socioeconomic status. According to consumption data for Acre, $54 \%$ of prime cuts are consumed by the highest income bracket compared to $22 \%$ for lower income consumers, who eat more secondary and other cuts (IBGE POF 2010).

Rural rubber tappers, colonists, and urban working class respondents have strikingly similar preferences, with the average of each group standing at 1.7 (out of four). This is likely a reflection of their relatively lower socioeconomic status and purchasing power, which makes higher-quality cuts of meat out of their price range. Cowboys prefer higher quality cuts (2.3), again a reflection of their unique position in beef cattle raising operations, where they have access to beef and cuts beyond the buying power of their socioeconomic status. Among urban professionals and NGOs (both 2.6) and policymakers and ranchers (both 2.8) we also see clear similarities in preferences for cuts of beef that are notably higher than rural and working class groups, excluding the cowboys.

While quantity of meat consumed is often the key indicator of development, this is a coarse measure of status in Acre, where beef is now cheap and available to most consumers. In this developing setting, then, it is not so much a difference between those who consume beef and those who cannot afford to; rather, status and inequality is expressed through the upper class's ability to buy superior cuts of beef.

Local perceptions of development mirror those of modernization theory and other linear views of development, in which increasing socioeconomic status allows one to move up the "animal proteins ladder" (Weis 2013). Economic behaviors of consumption and production are understood, both in global economic indicators and local perceptions, to be indicative of a group's position on a schema that is both hierarchical and ordered according to a process that is linear, or oriented to a final, better stage. By situating different foods, meats, and cuts of beef in relation to social categories of class, strength, and development, it is possible to see how overlapping evolutionary hierarchies inform systems of classification and how consumption and production are part of a shared conceptualization of the development process. The terms "developing", "emergent", or "industrializing" indicate that a process of moving from a lower category to a higher one is underway, but it is uncertain if the full metamorphosis to "developed" will be realized. The following section illustrates how this evolutionary conceptualization of development is used to interpret Acrean history and the present stage, in which the state is said to be "developing." 


\section{Beef and the development process in Acre}

In Acre, people often say that the state is "not like it was before." The past that they are referencing is described as atrasado (backward) or subdesenvolvido (underdeveloped). When I ask people about how it used to be in Acre during this time (roughly before and through the 1970s), many offer detailed descriptions of muddy streets, impassable roads, infrequent electricity, and shortages of key supplies. They also make a point of recounting how beef was in short supply. Citizens and servants would line up at dawn at the butcher shop, with little control over what cuts they would take home. Time after time, the scarcity of beef was mentioned as a hardship, while the expanded selection and affordability of beef in the present was held up as evidence for just how far the state had come.

Dramatic transformations occurred in Acre in the 1980s. The military government's plan to integrate Amazonia into the national economy through the promotion of colonization and investment was matched by some Acrean politicians and investors, who sought to inject life into an economy and society still oriented to the ever-declining rubber trade. One advertisement by a real estate company demonstrates the sort of propaganda aimed at investors in south-central and southern Brazil. The advertisement features the state of Acre as a tempting cut of prime beef ready to be eaten by investors (Figure 4). Ranchers arrived and converted forests to cattle pastures, resulting in the much publicized destruction, land conflict, and rubber tapper movement. While this was certainly a tumultuous time for Acreans, it was also seen as the point at which the state started to "develop." The actions of the national and state governments were key to this development, but so too were the contributions of migrants, who opened up businesses, brought new services, technologies and capital, and made this remote state more integrated with the rest of Brazil.

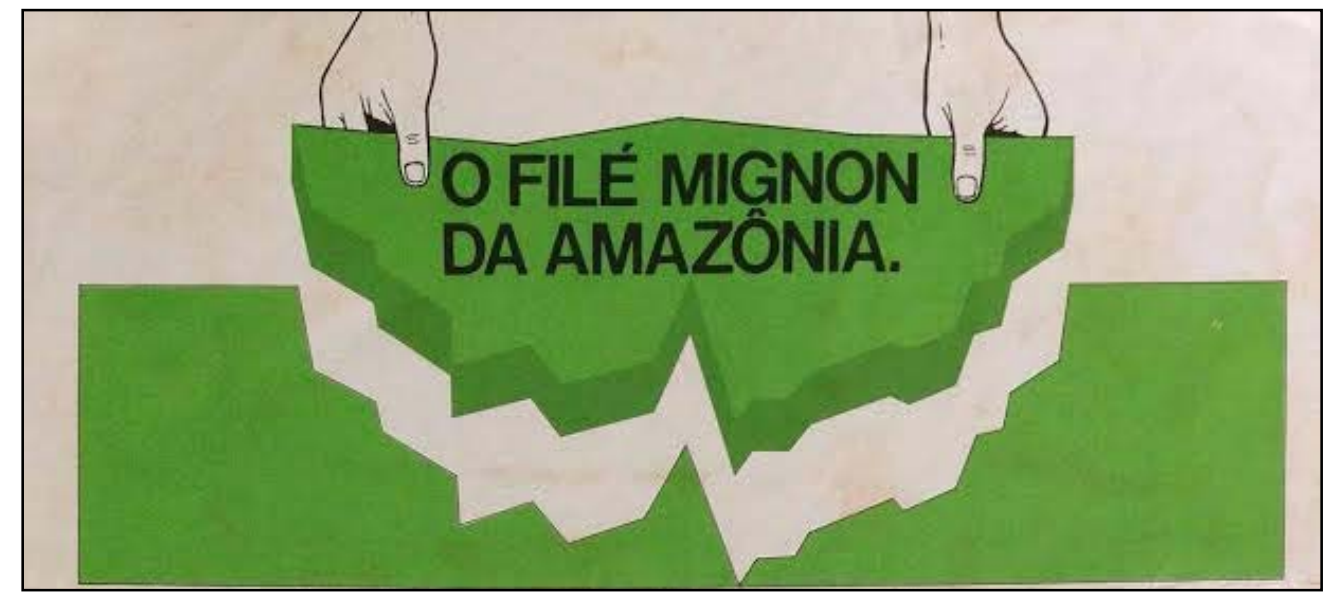

Figure 4: Image from a flyer advertising Acrean land to investors, with the phrase The filet mignon of Amazonia written on the state of Acre. Flyer published by Terra do Acre Melhoramentos Limitada [Acre Land Improvement Company]. The date does not appear on the flyer; it is likely from 1984 or 1985. From the Comissão Pastoral da Terra [Pastoral Land Commission] archives in Rio Branco, Acre through Katherine Lehman.

During the bulk of my fieldwork, 'Lula', (Luiz Inácio da Silva, 2003-2011) was the president of Brazil. A man of humble beginnings, Lula rose through the ranks of the metalworker's union, and eventually became presidential candidate for the Partido dos Trabalhadores (PT or Worker's Party), promising advances for the workers and disadvantaged of Brazil. Lula traveled far and wide in his many years of campaigning and any rural homes proudly displayed weathered photographs of the residents posing with Lula during his stops in Acre. Lula's ascendance as a worker is especially important to lower and working class Acreans, both rural and urban, and he is credited with the improved standard of living that many experienced in the early 2000s. 
This improvement resulted from the overall growth in the economy throughout Brazil, but also because of specific programs that directly benefitted rural Acreans, such as the Bolsa Familia (a social welfare program based on cash transfers to poor households) and Luz para todos (light for all), a rural electrification project. The state "forest government," also of the PT and in power during this time, is similarly credited with these improvements by many Acreans.

One man described this period of growth and transformation as the transition from the ovo to bife (from egg to beef cutlet) in the marmita (lunch pail) of Brazilian workers. The egg provides the minimal acceptable level of protein and is sometimes called by the bife de olhão or the jealous or big-eyed person's beef. It is said that the person with just an egg in their lunch looks on with envy (big eyes) as others eat beef. Manual laborers did not mention the relationships between class and meat, but they did relate beef to ideals of masculinity based on strength and hard work. In communal lunchtime conversations there was a relaxed atmosphere, and more than once it was suggested that a man who did not eat beef would wilt under the afternoon sun, while the beef-eater would thrive in his work and still have energy to fuel romantic activities during the night.

Beef, with its connotations of both strength and status, is seen as the symbolic and material fuel for labor needed to transform a place of underdevelopment and nature into a developed cultural landscape. Eating beef brings individual distinction, but it also brings the state and its citizens closer to a shared notion of what it is to be Brazilian, and what it is to be Brazilian now, during a time of emergence. For Amazonians located at the forested margins of nation, emergence takes on additional importance as they move closer to the core by distancing themselves from the forest and creating a cultural landscape comprised of modern cities and cultivated rural spaces.

Rural laborers and smallholders perform various improvements to their properties by clearing the hurdle that is the forest to create "land" for cultivation. Where migrants once saw the tangled, unproductive forest, they now gaze proudly from their porches at their "clean" pastures and grazing cattle. In the cities, construction workers are transforming vacant lots and neighborhoods of ramshackle homes into high rise apartments. Middle and upper class residents that I know have traded in their homes for the comfort and security of these enclosed and luxurious buildings. The growing skyline of Rio Branco, which now includes international hotel chains, such as Holiday Inn, are pointed to as signs of development for many Acreans and these are the types of places that visitors and affluent locals seeks out.

The present, for many, is a time in which the state of Acre is "developing." The development process includes improved health care and schools, as well as paved roads, cable television, and other amenities associated with emergence of new consumers, such as cars, motorcycles, computers, and appliances (Myers and Kent 2013). Every year that I return I am told with some enthusiasm about what is new in the area (e.g. the opening of the mall, a sushi restaurant, smart phones). These and other material objects, technologies, and constructions have made life better, easier, or more comfortable, and are seen as evidence of development. The process of developing is occurring in Acre through the transformation of various spaces into agricultural and cultural sites that collectively signal development, to both urban and rural locals and visitors.

The paving of the BR-317 highway in the early 2000s is perhaps the most widely recognized improvement in the state, especially for rural people. The highway connects the countryside with the city, carrying cattle and timber to city for processing and transport, and also brings families from the forest to cities for basic services and supplies that many now consider crucial to the continuation of rural life. Drawn by schools, hospitals, and jobs, many rural residents have moved to city for good. On weekends and holidays, many journey back to visit family and friends in the countryside, where they will often enjoy churrasco and the simplicity and "purity" of life out of the city. These urbanites with rural roots hop off the bus at the edge of the highway, remove their city shoes, and roll up their pant legs in preparation for the mud and muck that lies ahead. They tie plastic sacks of purchased food and gifts together, balance the load on their shoulders, and proceed down the little dirt roads and trails. On Sunday afternoon, or after the holiday has ended, they will be back on the side of the road in their clean shoes, waiting for the bus to take them back to the city for the jobs, school, and services that drew them from the countryside to the city. 
The inconspicuous dirt roads off the side of the highway may go unnoticed to the affluent travelers and tourists who now travel the 'Highway of the Pacific' to get to Machu Picchu in Peru. These visitors from the developed south of Brazil know of Acre as a place of the forest and "the land of Chico Mendes." The hotels in Rio Branco catering to these travelers feature paintings of jaguars and scarlet macaws and scenes of indigenous and rubber tapper daily life. It is assumed that this natural, forested version of Amazonia is what sophisticated visitors want to see. While tourists enjoy discovering Amazonian foods and are surprised by some of the amenities, Acre is usually just a brief stopover en route to see "culture" and ruins in Peru. The idea of international travel and leisure is appealing to Acreans, and many see it as element of the good life that comes from personal success that is more attainable in the developed south. While Acreans agree that things are getting better and that Acre is developing, few would say that the state has completed the metamorphosis to "developed." Becoming developed requires leaving the shadow of the forest and the stereotypes of the indolent forest dweller through transformation of the Acrean society, its people, and landscape. In developing Acre, beef is an indicator of development, and also the symbolic and nutritional fuel for continued growth and improvement.

\section{Conclusion}

This article described linkages between conceptual categories, perceptions, and behaviors that help to understand the growing demand for beef in Acre, Brazil. The findings contribute a local analysis to macrolevel research on connections between consumption, production, and environmental impacts, and show why new consumers in a developing setting choose to eat more beef. Economic, demographic, and policy factors certainly structure consumption, but the decision to eat meat is also related to cultural and social considerations; these "invisible" factors are often mentioned in macro-level environmental research, but they are ultimately considered too place-specific or difficult to measure to contribute to explanations (e.g. Eshel et al 2014. McAlpine et al. 2009). Social and cultural dimensions of consumption can be accessed by scaling down to study the local context, but in order to understand local perspectives and the cultural and ideological factors that structure consumption it is necessary to put aside the normative framing of destruction and consumption as negative processes.

In the agricultural frontiers and rural areas of Latin America, commodities such as beef, soy, and sugarcane are produced through the transformation of the environment. Much of the research and press coverage of these transformations emphasizes the destruction required to provide food, fuel, and fodder for developed and developing nations, often in North America, Europe, and Asia. According to this negative destruction - consumption framing, the livestock industry destroys priceless biodiversity, habitat, and carbon sinks, and at the same time produces negative by-products across scales, including GHG emissions, effluents, and arterial plaque. In comparison with profit, yield, GDP and other indicators touted in economic development measures and livestock industry reports, the losses and harmful products of destruction are invisible and difficult to quantify, and they are often written off, ignored, and concealed as externalities (Weis 2013).

A local perspective emphasizing the consumption of the same products that are often scrutinized in macro-level research reveals how local populations perceive and participate in destruction/ production. In Acre, a site of protest to destructive development and home to policies for forest-based development, consumers are aware of the negative side of cattle production and beef consumption. Why then do Acreans choose to eat beef? Some Acreans ignore or care little about the destruction of expanding cattle production, while others downplay the negative transformations to defend their interests. Yet, many are aware of the troubling connections and nonetheless consume beef. For example, we might expect that the members of local socio-environmental NGOs, who spend their days working for sustainable livelihoods and disdain the cattle ranchers, would reject the beef that comes directly from that industry. The NGOs are an extreme example at the environmentalist end of the spectrum that see the destruction and fight against it, but they are similar to less-critical Acreans in that they choose to eat beef on a regular basis. In order to understand this disconnect between ideology and behavior, and the overall high rates of beef consumption, it is necessary to contextualize all of these actors in a shared "developing" context. Many Acreans have grown up learning that humans need meat to be healthy, and that to be Brazilian is to crave beef. The allure of beef and meat is 
particularly strong because it was previously scarce or inaccessible. Cultural perceptions and traditions that associate beef with sociality, vigor, and status map onto an ideology of linear development, stressing growth and improvement. Consumption of beef seems to be a logical next step according to an evolutionary hierarchy in which class distinctions and food types run parallel. In this linear vision of development, individuals distinguish themselves through consumption, but also signal their shared commitment to Brazilian identity, and contribute to regional development through the transformation of the landscape. Meat is thus a symbol of class, identity, and development, but it also the nutritional and metaphorical fuel, providing strength and endurance to the workers transforming the environment, from high-rise apartments encircling the city (where residents eat fine cuts of beef) to the paved roads that now connect the city with the countryside, where cultivated pastures replace the forest.

In a setting where destruction is directly linked to the beef that is consumed, people may not overlook or ignore the negative impacts of the cattle industry. Rather, they are capable of forgetting or at least putting aside the negative connections in the social situations when decisions are made about what to eat. The accumulated weight of cultural beliefs and preferences coupled with the ideology of development naturalizes the allure of beef for most Acreans, and makes it difficult to avoid for those who are critical of it. As the few Acrean vegetarians that I could find can attest, no one is forced to eat beef, but diets are patrolled by friends, family and strangers (e.g. wait staff), and the rejection of beef is met with utter confusion, concern, and suspicion. The reorganization of production also facilitates the snipping of connective threads. Forest destruction, GHG emissions, the slaughter of living animals, and other negative aspects and impacts of the chain of production are essentially invisible to the consumer or occur far from the sites of consumption. The accumulated rubble from each stage of production, processing, and distribution is not seen. Most consumers see only the fetishized final product - hunks of sculpted beef at the butcher shop, perfect cuts wrapped tight in cellophane at the grocery store, or sizzling beef dripping grease onto coals at the churrascaria or churrasco. A focus on links between consumption and production/ destruction in developing Acre shows how the erasure of these very connections is integral to the continuation and expansion of the capitalist system. The rubble at this stage is swept away, hidden, or ignored and then repackaged as beef. This beef becomes delicious and healthy through the optics of local cultural beliefs and practices, development discourse and ideology, and the disarticulated economic organization of the industry.

\section{References}

Arima, E.Y., P. Richards, R. Walker and M.M. Caldas. 2011. Statistical confirmation of indirect land use change in the Brazilian Amazon. Environmental Research Letters 6(2): 024010.

Austin, K. 2010. The "hamburger connection" as ecologically unequal exchange: a cross-national investigation of beef exports and deforestation in less-developed countries. Rural Sociology 75(2): 270-299.

Bakx, K. 1988. From proletarian to peasant: rural transformation in the state of Acre, 1870-1986. The Journal of Development Studies 24(2):141-160.

Barona, E., N. Ramankutty, G. Hyman and O.T. Coomes. 2010. The role of pasture and soybean in deforestation of the Brazilian Amazon. Environmental Research Letters 5(2): 024002.

Besky, S. 2013. The Darjeeling distinction: labor and justice on fair-trade tea plantations in India. Berkeley: University of California Press.

Browder, J.O. 1988. The social costs of rain forest destruction: a critique and economic analysis of 'the hamburger debate.' Interciencia 13(2): 115-120.

Bryant, R.L. and M.K. Goodman. 2004. Consuming narratives: the political ecology of 'alternative' consumption. Transactions of the Institute of British Geographers 29(3): 344-366.

Bourdieu, P. 1984. Distinction: a social critique of the judgment of taste. Cambridge: Harvard University Press.

Bunker, S.G. 1985. Underdeveloping the Amazon: extraction, unequal exchange, and the failure of the modern state. Chicago: University of Chicago Press. 
Campbell, J.M. 2015. Conjuring property: speculation and environmental futures in the Brazilian Amazon. Seattle: University of Washington Press.

Censo Agropecuário [Agricultural Census] 2006 [accessed June 27 2016]. http://www.ibge.gov.br/home/estatistica/economia/agropecuaria/censoagro/2006_segunda_apuracao/d efault tab_uf xls.shtm

Chemnitz, C. and S. Becheva (eds.). 2014. Meat atlas: facts and figures about the animals we eat. Germany: Heinrich Böll Foundation.

DeWalt, B.R. 1983. The cattle are eating the forest. Bulletin of the Atomic Scientists 39(1): 18-23.

Douglas, M. 1972. Deciphering a meal. Daedalus Winter: 61-81.

Douglas, M. 2003. Purity and danger: an analysis of concepts of pollution and taboo. London: Routledge.

Edelman, M. 1989. From Costa Rican pasture to North American hamburger. In M. Harris and E.B. Ross (eds.). Food and evolution: toward a theory of human food habits. Philadelphia: Temple University Press. Pp. 541-561.

Edelman, M. 1995. Rethinking the hamburger thesis: deforestation and the crisis of Central America's beef exports. In M. Painter and W.H. Durham (eds). The social causes of environmental destruction in Latin America. Ann Arbor: University of Michigan Press. Pp. 25-62.

Eshel, G., A. Shepon, T. Makov, and R. Milo. 2014. Land, irrigation water, greenhouse gas, and reactive nitrogen burdens of meat, eggs, and dairy production in the United States. Proceedings of the National Academy of Sciences 111(33): 11996-12001.

Fajans, J. 2013. Brazilian food: race, class and identity in regional cuisines. London: Bloomsbury.

Faminow, M.D. 1997. Spatial economics of local demand for cattle products in Amazon development. Agriculture, Ecosystems and Environment 62(1): 1-11.

Foweraker, J. 1981. The struggle for land: a political economy of the pioneer frontier in Brazil from 1930 to the present day. Cambridge: University of Cambridge.

Ferreira, A. 1951. Fazendeiro. In Ferreira, A. Xenhenhém. Rio de Janeiro: José Olympio.

FAOstat. Food and Agriculture Organization Website. [accessed September 15, 2016] http://faostat3.fao.org

Gibbs, H.K., J. Munger, J. L'Roe, P. Barreto, R. Pereira, M. Christie, T. Amaral and N.F. Walker. 2016. Did ranchers and slaughterhouses respond to zero-deforestation agreements in the Brazilian Amazon? Conservation Letters 9(1): 32-42.

Gomes, C.V. 2009. Twenty years after Chico Mendes: extractive reserves' expansion, cattle adoption and evolving self-definition among rubber tappers in the Brazilian Amazon. Ph.D. dissertation. Gainesville, FL: University of Florida.

Goodland, R., and J. Anhang. 2009. Livestock and climate change: what if the key actors in climate change are... cows, pigs, and chickens? Washington, D.C.: Worldwatch Institute.

Gordillo, G. 2014. Rubble: the afterlife of destruction. Durham N.C.: Duke University Press. Academia, intro Greenpeace. 2015. Grilling away the Amazon. São Paulo: Greenpeace Brasil.

Harris, M. 1998. Good to eat: riddles of food and culture. Long Grove, IL: Waveland Press.

Hecht, S.B. 1993. The logic of livestock and deforestation in Amazonia. BioScience 43(10): 687-695. Researchgate

Hecht, S.B. and A. Cockburn. 1989. The fate of the forest: developers, destroyers and defenders of the Amazon. London: Verso.

Heyman, J.M. 2005. The political ecology of consumption: beyond greed and guilt. In Paulson, S. and L.L. Gezon (eds). Political ecology across spaces, scales, and social groups. New Brunswick, NJ: Rutgers University Press. Academia

Hoelle, J. 2015. Rainforest cowboys: the rise of ranching and cattle culture in Western Amazonia. Austin: University of Texas Press.

IBGE- Instituto Brasileiro de Geografia e Estatística [Brazilian Institute of Geography and Statistics]. 2016. [accessed June 27 2016]. http://www.ibge.gov.br/estadosat/temas.php?sigla=ac\&tema=pecuaria2014 
IBGE POF- Pesquisa de Orçamentos Familiares [Household Budget Survey]. 2010. [accessed June 27, 2016] http://www.ibge.gov.br/home/estatistica/populacao/condicaodevida/pof/2008_2009/

Kaimowitz, D., B. Mertens, S. Wunder and P. Pacheco. 2004. Hamburger connection fuels Amazon destruction. Bogor, Indonesia: Center for International Forestry Research.

Kainer, K.A., M. Schmink, A.C. Pinheiro Leite and M.J. da Silva Fadell. 2003. Experiments in forest-based development in Western Amazonia. Society and Natural Resources 16(10): 869-886.

Keck, M.E. 1995. Social equity and environmental politics in Brazil: lessons from the rubber tappers of Acre. Comparative Politics 27(4): 409-424.

Lyon, S. 2010. Coffee and community: Maya farmers and fair-trade markets. Boulder: University Press of Colorado.

McAlpine, C.A., A. Etter, P.M. Fearnside, L. Seabrook and W.F. Laurance. 2009. Increasing world consumption of beef as a driver of regional and global change: a call for policy action based on evidence from Queensland (Australia), Colombia and Brazil. Global Environmental Change 19(1): 21-33. Academia

Mintz, S.W. 1985. Sweetness and power. New York: Viking.

Mintz, S.W. and C.M. Du Bois. 2002. The anthropology of food and eating. Annual Review of Anthropology 31(1): 99-119.

Myers, N. 1981. The hamburger connection: how Central America's forests become North America's hamburgers. Ambio 10(1): 3-8.

Myers, N. and J. Kent. 2013. The new consumers: the influence of affluence on the environment. Washington, D.C.: Island Press.

Nations, J.D. and D. Komer. 1983. Rainforests and the hamburger society. Environment: Science and Policy for Sustainable Development 25(3): 12-20.

Nations, J.D. and R.B. Nigh. 1978. Cattle, cash, food, and forest: the destruction of the American tropics and the Lacandon Maya alternative. Culture and Agriculture 16(6): 1-6.

Oliveira, G. and S.B. Hecht. 2016. Sacred groves, sacrifice zones and soy production: globalization, intensification and neo-nature in South America. The Journal of Peasant Studies 43(2): 251-285. Researchgate

Oliveira, G. and M. Schneider. 2016. The politics of flexing soybeans: China, Brazil and global agroindustrial restructuring. The Journal of Peasant Studies 43(1): 167-194.

Pacheco, P. 2012. Soybean and oil palm expansion in South America: a review of main trends and implications. CIFOR Working Paper No. 90. Bogor, Indonesia: Center for International Forestry Research.

Shane, D. 1986. Hoofprints on the forest. Philadelphia: Institute for the Study of Human Issues.

Rimas, A., and E. Fraser. 2008. Beef: the untold story of how muscle, meat and milk shaped the world. New York: William Morrow/Harper Collins.

Schmink, M., A. Duchelle, J. Hoelle, F. Leite, M. Vinício d'Oliveira, J. Vadjunec, J. Valentim, and R. Wallace. 2014. Forest citizenship in Acre, Brazil. In Katila, P., G. Gallowa, W. de Jong, P. Pacheco, and G. Mery (eds.). Forest under pressure: local responses to global issues. Finland: IUFRO.

Schmink, M. and M. Lima Cordeiro. 2008 Rio Branco: a cidade da florestania. Belém: Universidade Federal do Pará. (Rio Branco: the city of the forest)

Schmink, M. and C. Wood 1992. Contested frontiers in Amazonia. New York: Columbia University Press.

Schneider, M. 2017. Wasting the rural: meat, manure, and the politics of agro-industrialization in contemporary China. Geoforum 78: 89-97.

Schumpeter, J. 1942. Capitalism, socialism and democracy. New York: Harper and Brothers.

Simoons, F.J. 1984 [1961]. Eat not this flesh: food avoidances in the Old World. Madison: University of Wisconsin Press. 
Steinfeld, H., P. Gerber, T. Wassenaar, V. Castel, M. Rosales and C. De Haan. 2006. Livestock's long shadow: environmental issues and options. Rome: FAO.

Uhl, C. and G. Parker. 1986. Our steak in the jungle. BioScience 36(10): 642-642.

Vadjunec, J.M., M. Schmink and A.L. Greiner. 2011. New Amazonian geographies: emerging identities and landscapes. Journal of Cultural Geography 28(1): 1-20.

Valentim, J.F. 2012 Evolução da produção agropecuária no Acre (Evolution of agricultural production in Acre). EMBRAPA-Acre.

Walsh, C. 2004. Eugenic acculturation: Manuel Gamio, migration studies, and the anthropology of development in Mexico, 1910-1940. Latin American Perspectives 31(5): 118-145.

Wilk, R. 2002. Consumption, human needs, and global environmental change. Global Environmental Change 12(1): 5-13.

Weis, T. 2013. The ecological hoofprint: the global burden of industrial livestock. London: Zed.

Zycherman, A. 2016. Cultures of soy and cattle in the context of reduced deforestation and agricultural intensification in the Brazilian Amazon. Environment and Society 7(1): 71-88. 